\title{
Phytometric characteristics and chlorophyll index of "Paiaguás" grass (Urochloa brizantha) as a function of wood ash doses and soil water stress
}

\author{
Maria Débora Loiola Bezerra ${ }^{1}$, Edna Maria Bonfim-Silva*2, Tonny José Araújo da Silva² ${ }^{2}$ André Pereira \\ Freire Ferraz ${ }^{2}$, Ana Paula Alves Barreto Damasceno²
}

\author{
${ }^{1}$ Federal University of Mato Grosso - UFMT, Faculty of Agronomy and Zootechny, 2367 Fernando Corrêa da Costa \\ Avenue, Cuiabá, 78060-900, Brazil \\ ${ }^{2}$ Federal University of Mato Grosso - UFMT, Institute of Agricultural and Technological Sciences, 5055 Students \\ Avenue Rondonópolis, 78.735-901, Brazil
}

*Corresponding author: embonfim@hotmail.com

\begin{abstract}
The objective of this study was to evaluate the phytometric characteristics and chlorophyll index of paiaguás grass (Urochloa brizantha) fertilized with wood ash doses and soil water availability. The experiment was carried out in a randomized complete block in a $5 \times 5$ fractional factorial scheme (five doses of wood ash: $0,8,16,24$ and $32 \mathrm{~g} \mathrm{dm}^{-3}$, and five soil water stresses: 4, 8, 16, 32 and $64 \mathrm{kPa}$ ), with four replicates. The experimental design was based on the modified central compound, in which 13 combinations of wood ash doses and soil water availability were studied. Each experimental unit consisted of a pot containing $8.7 \mathrm{dm}^{3}$ of soil and five plants. Three harvests were performed every 30 days after planting, in a 90-day experimental period. At each harvest, plant height, leaf angle, leaf area, stem diameter, and chlorophyll index (SPAD reading) were evaluated. The best results for the phytometric characteristics and chlorophyll index of paiaguás grass were observed in the wood ash dose of $21 \mathrm{~g} \mathrm{dm}^{-3}$. There was a reduction of growth and grass chlorophyll content in the soil water tension of $41.20 \mathrm{kPa}$.
\end{abstract}

Keywords: leaf angle, leaf area, plant height, soil water tension, solid residue in agriculture.

Abbreviations: Al_Aluminum; B_Total Boron; Ca_Calcium; CEC_Cation exchange capacity at pH 7.0; Cu_Total Copper; DAS_days after sowing; EMBRAPA_Empresa Brasileira de Pesquisa Agropecuária; H_Hydrogen; K_Potassium; $_{2} \mathrm{O} \_$Potassium; LAl_leaf area index; m_aluminum saturation; Mg_Magnesium; Mn_Total Manganese; N_Nitrogen; Na_Sodium; O.M._Organic matter; P_Phosphorus; $\mathrm{P}_{2} \mathrm{O}_{5}$ Phosphorus in neutral ammonium citrate and water; PAR_Photosynthetically active radiation; $\mathrm{PH} \_\mathrm{Plant}$ height; PN_Neutralization power; PRNT_Relative neutralizing power; Si_Silicon; SO__Sulfur; SPAD_Soil Plant Analysis Development; V_Base saturation; WA_Wood ash; Zn_Total Zinc.

\section{Introduction}

The fertilization of tropical grasses by means of wood ash has been objective of study by several authors (Bonfim-Silva et al., 2015; Bezerra et al., 2016). These authors have found greater growth, biomass production and increase in macronutrient concentrations (Santos et al., 2014) in cultivars of Urochloa brizantha (Hochst. ex A. Rich.) R.D. Webster (syn Brachiaria brizantha) grown on tropical soils fertilized with wood ash.

The choice of forage grass and its management of fertilization are very important for the production of meat and milk under pasture. Thus, U. brizantha cv. BRS Paiaguás presents as an alternative for pasture diversification in tropical regions, mainly during the dry season, as it has a high yield of leaves with good nutritive value, resulting in higher weight gains per animal per area (Valle et al., 2013; Euclides et al., 2016). Wood ash has been shown to neutralize soil acidity and provide nutrients such as calcium, magnesium, potassium, phosphorus and micronutrients, which are essential for plant growth and development (Chen et al., 2015; Symanowicz et al., 2018). Most of the bioenergy produced in the world is derived from plant biomass (Souza et al., 2017). The combustion of this material leads to the production of large quantities of ash, about 480 million tons annually, worldwide, and one of the main issues regarding the burning of phytomass for power generation concerns the destination of this large amount of ash produced (Vassilev et al., 2013).

Fertilization with wood ash may contribute to the destination of this solid residue in agriculture safely and in the performance of paiaguás grass during periods of drought. In addition, the use of this solid residue in agriculture is a reality for many years. In a long-term experiment (30 years), Saarsalmi et al. (2012) found that the application of wood ash, associated to nitrogen fertilization, was linked to improvements in soil fertility and biological activity and plant growth compared to the exclusive use of nitrogen. On the other hand, Malmgren and Riley (2012) pointed out that the use of wood ash as fertilizer is an area that needs to be developed as a way of applying this residue. In this sense, Ring et al. (2006) concluded that the application of 3 tonnes ha $^{-1}$ of shredded ash resulted in 
increased potassium, sodium, sulfate and total organic carbon content of the soil up to $50 \mathrm{~cm}$ depth of soil.

In addition to the supply of nutrients, soil water availability is one of the factors that most limit plant production, directly influencing the morphological characteristics of plants. Koetz et al. (2017) evaluated the growth of $U$. brizantha cv. Paiaguás under soil water stress and verified that the highest productive performance of the crop was obtained when the tension was between 29 and $34 \mathrm{kPa}$. Bahrani et al. (2010) found a reduction in plant height and leaf area of several forage kind of grass submitted to water deficit compared to those irrigated to field capacity.

The objective of this study was to evaluate the phytometric characteristics and the chlorophyll index of paiaguás grass (U. brizantha) fertilized with doses of wood ash and soil water availability.

\section{Results and Discussion}

\section{Effect of wood ash and soil water on plant height}

There was a significant interaction between the wood ash doses and soil water stresses only for the plant height variable, in the three harvests (Fig 1).

The response surface study (Fig 1A) showed that the dose of wood ash of $19.05 \mathrm{~g} \mathrm{dm}^{-3}$ associated with soil water tension of $53.65 \mathrm{kPa}$, provided the highest plant height $(53.55 \mathrm{~cm})$ in Paiaguás grass, at 30 days after sowing (DAS).

In the second harvest (60 DAS), the highest plant height of $55.48 \mathrm{~cm}$ (Fig 1B) was observed when a $20.13 \mathrm{~g} \mathrm{dm}^{-3}$ wood ash dose combined with the soil water tension of $47.29 \mathrm{kPa}$. In the third evaluation, the plants height of $49.26 \mathrm{~cm}$ was achieved, higher than those observed upon application of $23.51 \mathrm{~g} \mathrm{dm}^{-3}$ wood ash associated with water tension in the soil of $48.03 \mathrm{kPa}$ (Fig 1C).

Throughout the three harvests, we was found that the highest plant heights was occurred even under high water tensions in the soil, where soil moisture is lower. This can be attributed to the presence of wood ash that increased the retention of water in the soil and favored the growth of grass, despite the low water availability. This demonstrates that the incorporation of the residue into the soil may potentiate the development of Paiguás grass in the dry season of Cerrado. In this sense, Euclides et al. (2016) found that cv. Paiaguás presented higher forage accumulation (17.2 $\left.\mathrm{kg} \mathrm{ha}^{-1} \mathrm{day}^{-1}\right)$ in relation to $\mathrm{cv}$. Piatã $\left(6.0 \mathrm{~kg} \mathrm{ha}^{-1} \mathrm{day}^{-1}\right)$ during the dry season of the year.

In addition to increasing soil water retention, wood ash provided nutrients to Paiaguás grass, such as $\mathrm{Ca}, \mathrm{Mg}, \mathrm{K}$ and $P$, necessary for plant development. Symanowicz et al. (2018), analyzed ashes and observed good physical and chemical properties and confirmed that they are a source of the macronutrients $\mathrm{Ca}, \mathrm{C}, \mathrm{K}, \mathrm{Mg}, \mathrm{P}, \mathrm{S}$ and $\mathrm{N}$ for plants, being suitable for agricultural soils. Similarly, Bezerra et al. (2016) investigated the effect of application of wood ash on growth of $U$. brizantha $\mathrm{cv}$. Marandu and found greater height of the grass with the application of the residue to the soil.

In addition, throughout the harvests, we observed that in order to reach higher heights of the grass, it is necessary to obtain higher doses of wood ash: $19.05 \mathrm{~g} \mathrm{dm}^{-3}$ in the first harvest, 20.13 and $23.51 \mathrm{~g} \mathrm{dm}-3$, in the second and third harvests, respectively. This may be due to a greater demand for nutrients by grass, since there was no replacement of the residue in the soil at the time of evaluations. In another study, Euclides et al. (2016) observed 29.2 and $30.2 \mathrm{~cm}$ heights of paiaguás grass, in the dry and humid season, respectively.

For paiaguás grass, Costa and Queiroz (2017) suggested a maximum height of $35 \mathrm{~cm}$ under continuous grazing. In the present study, throughout the three harvests, plant heights were greater than $50 \mathrm{~cm}$. This may be an indication that it is possible, under continuous grazing, to increase the stocking rate to lower the grass. In a rotational stocking system, we anticipate the plant harvest or the grazing period for less than 30 days.

The evaluation of the plant height is easy and quick, being favorable for the management of pastures. This indicates the moment of entry and exit of animals in the area. The canopy height also correlates and influences the structural characteristics and the mass of the forage (Santos et al., 2017), making possible the understanding of these structures and the behavior of the animals to plant variations (Fonseca et al., 2013). Dabrowski et al. (2013) found a high correlation coefficient between plant height and leaf area index.

\section{Effect of wood ash and soil water on leaf angle}

The leaf angle did not show a significant effect on the interaction between the doses of wood ash and soil water stresses. Thus, in the first evaluation, a leaf angle adjustment to the quadratic regression model was observed (Fig 2A), in which the wood ash dose of $13.45 \mathrm{~g} \mathrm{dm}^{-3}$ provided the lowest leaf angle $\left(26.85^{\circ}\right)$.

In the second harvest, the leaf angle presented an isolated effect for wood ash (Fig 2A) and soil water tension (Fig 2B), adjusting to the quadratic and linear regression models, respectively. The lowest value of leaf angle (17.84ㅇ) was verified using the wood ash dose of $17.82 \mathrm{~g} \mathrm{dm}^{-3}$. Soil water tension of $64 \mathrm{kPa}$ increased leaf slope by $32.16 \%$.

In the third harvest, the leaf angle did not present significant difference for the doses of wood ash and tensions of water in the soil. However, in the first and second harvests, the leaf angles were smaller with the addition of the wood ash to the soil. The wood ash used in this study contains a high content of silicon (274.4 $\mathrm{g} \mathrm{kg}^{-1}$ ) (Table 2). This nutrient is important because it favors the plant architecture and maintains it more erect, providing a smaller leaf inclination for interception of solar rays (Epstein, 1999).

Truong et al. (2015) found that smaller leaf angles provided greater penetration of solar radiation in the canopy of plants, increasing the biomass production potential of sorghum. These authors clarified how efficiently a plant intercepts solar radiation. This efficiency is determined by leaf angle, by which we understood that changes in plant architecture affect plant productivity and performance.

Canopy architectures in which the upper leaves have smaller angles redistribute the photosynthetically active radiation (PAR) more evenly along the canopy to the lower leaves; thus, reducing senescence induced by shading of the lower leaves (Song et al., 2013; Drewry et al., 2014).

This regulation in the penetration of the solar rays provided by the foliar inclination maximizes the carbon accumulation, by optimizing the interception of the photosynthetically active radiation (PAR), resulting in greater photosynthetic 
efficiency and, consequently, greater productive potential (van Zanten et al., 2010; Truong et al., 2015).

In the second harvest, we verified that the increase of soil water tensions provided increase in leaf angle, in which greater leaf opening took place due to water stress. In water stress conditions, plants develop selective survival strategies, in which larger leaf angles decrease rainfall interception and provide direct water drop in the soil, resulting in greater water availability for the roots (Koch et al., 2009). Results obtained by Holder (2012) indicated that water droplets intercepted during a rainfall event are likely to drain from leaf surfaces, which contribute to waterfall due to leaf angle exceeding water retention capacity in most species examined in semi-arid regions.

\section{Effect of wood ash and soil water on leaf area}

For the variable leaf area, there was no significant interaction between the sources of variation (doses of wood ash and soil water stresses) in three evaluated harvests. In the first evaluation, the leaf area of the plants adjusted to the quadratic regression model for both factors. The largest leaf area $\left(710.34 \mathrm{~cm}^{2}\right)$ (Fig $3 \mathrm{~A}$ ) was observed in the gray dose of $23.63 \mathrm{~g} \mathrm{dm}^{-3}$. Soil water tension of $49.23 \mathrm{kPa}$ caused the smallest leaf area $\left(105.55 \mathrm{~cm}^{2}\right.$ ) (Fig 3B). In the second evaluation of the forage grass, the leaf area adjusted to the linear regression model for the wood ash doses and the quadratic regression model for soil water tensions. The wood ash dose of $32 \mathrm{~g} \mathrm{dm}^{-3}$ increased the leaf area by 83.38\% (Fig 3A), compared with the absence of fertilization with wood ash. In the soil water tension of $47.54 \mathrm{kPa}$, the smallest leaf area of $59.89 \mathrm{~cm}^{2}$ was observed (Fig 3B). At 90 days after planting, the leaf area adjusted to the linear regression model, in which the maximum dose of wood ash increased in $95.74 \%$ (Fig 3A) of the leaf area in grass, compared to the absence of application of the residue. In relation to soil water tension (Fig 3B), there was an adjustment to the quadratic regression model for the leaf area, where the lowest value $\left(387.16 \mathrm{~cm}^{2}\right)$ was observed in the soil water tension of $45.30 \mathrm{kPa}$. Throughout the three forage harvests, we verified that through the incorporation of the wood ash to the soil, there was an increase in the leaf area. The wood ash used in the present study had nutrients such as potassium, calcium and magnesium (34.7, 33.0 and $21 \mathrm{~g} \mathrm{~kg}^{-1}$, respectively). According to Watson (1952), the leaf area is dependent on plant nutrition. In this way, leaves with larger exposed areas favor the interception of solar radiation, energy source for photosynthetic processes and photoassimilates synthesis. Leaf area and angle are related to solar radiation intercepted (absorbed) by the plant canopy and interfere with the efficiency of photosynthetically active radiation (PAR) absorption and its conversion to photoassimilates, since they regulate light penetration in the canopy (van Zanten et al., 2010). Behling et al. (2015) also added that, at the beginning of plant growth, the priority is to increase the leaf area to intercept more light. In the three harvests, we observed minimum points of leaf area of Paiaguás grass due to the high soil water tensions that restricts the development of crop. The same was reported by Santos et al. (2013) in a study of two cultivars, marandu and piatã grasses (U. brizantha), in response to low water availability conditions. Pezzopane et al. (2015) observed an average loss of $70 \%$ in the leaf area of $U$. brizantha cultivars under water deficit. According to these authors, BRS Paiaguás presented the smallest leaf area reduction compared to the other cultivars, Piatã, Marandu and Xaraés. According to Mahajan and Tuteja (2005) the reduction of leaf expansion is a strategy of plants under water deficit condition, since less exposure of leaf area results in reduction of transpiration. In spite of the low water availability to reduce leaf area of grass, we verified that from the first to the third harvest there was an increase in the leaf area (105.55 and $387.16 \mathrm{~cm}^{2}$, respectively) of plants. This can be attributed to the increase in soil water retention as well as nutrient availability by wood ash interfering with the development of grass leaf area. The leaf area influenced the population density of grasses (Kebrom and Mullet, 2015) and pasture growth rate. Likewise, Kebrom and Mullet (2015) affirmed that the photosynthetic leaf area determines the levels of sucrose that affect the growth of the tiller. Thus, a small change in the leaf area or photosynthetic activity may result in failure of the bud growth, resulting in a smaller number of final branching, alteration of the plant architecture, and initiation of a process of degradation of the pasture or cause the death of the plant.

\section{Effect of wood ash and soil water on stem diameter}

The stem diameter showed an isolated effect for wood ash and soil water stress in three evaluations. On the occasion of the first harvest ( 30 days after sowing), the stem diameter adjusted to the quadratic regression model (Fig 4A), where the highest value $(2.66 \mathrm{~cm})$ was obtained in the wood ash dose of $24.06 \mathrm{~g} \mathrm{dm}^{-3}$. In the second evaluation, the maximum stem diameter value, $2.39 \mathrm{~cm}$, (Fig 4A) was found at the dose of $21.76 \mathrm{~g} \mathrm{dm}^{-3}$. The soil water tension of $64 \mathrm{kPa}$ caused a reduction of $20.15 \%$ in the stem diameter of paiaguás grass (Fig 4B). On the occasion of the third harvest, stem diameter adjusted to the quadratic and linear regression models for wood ash doses and soil water tensions, respectively. The largest stem diameter of $2.47 \mathrm{~cm}$ was verified in the dose of wood ash of $22.51 \mathrm{~g} \mathrm{dm}^{-3}$ (Fig 4A). As soil water stress increased (Fig 4B), there was a progressive decrease in the response variable, representing a reduction of $19.31 \%$ in the stem diameter of the grass. It was observed that the wood ash incorporated in the soil provided increase in the stem diameter along the three harvests. In the second and third harvests, there was a decrease in stem diameter as there was a lower availability of water to the plants. The stem is the supporting structure of the plant and to support the weight of the other organs, such as leaves, the stem diameter changes in the same proportion (McMahon and Kronauer, 1976; Niklas, 1994). Thus, plants with larger stem diameter are generally more resistant to bedding (Bonfim-Silva et al., 2016). The stem diameter is directly related to nutritive values and quantitative aspects of forage plants, as well as to other structural characteristics of grasses, such as leaf and stem ratio, plant height and biomass production (Chaugool et al., 2013).

\section{Effect of wood ash and soil water on chlorophyll index}

The chlorophyll index (SPAD reading) showed an isolated effect only for doses of wood ash. In the first, second and third evaluations, the SPAD reading was adjusted to the quadratic regression model (Fig 5), where the highest values, 
Table 1. Chemical and granulometric analyzes of Dystrophic Oxisol $(0-20 \mathrm{~cm}$ layer) in an area under Cerrado vegetation, Rondonópolis-MT.

\begin{tabular}{|c|c|c|c|c|c|c|c|c|c|c|c|c|c|}
\hline \multirow{2}{*}{$\begin{array}{l}\mathrm{pH} \\
\mathrm{CaCl}_{2}\end{array}$} & $P$ & $\mathrm{~K}$ & $\mathrm{Ca}$ & $\mathrm{Mg}$ & $\mathrm{Al}$ & $\mathrm{H}$ & \multirow[t]{2}{*}{ CEC } & \multirow{2}{*}{$\begin{array}{l}\text { OM } \\
\mathrm{g} \mathrm{kg}^{-1}\end{array}$} & $\mathrm{~V}$ & $\mathrm{~m}$ & Sand & Silt & Clay \\
\hline & \multicolumn{6}{|c|}{$\mathrm{mg} \mathrm{dm}^{-3}$} & & & ...... & $\ldots$. & ......... & $g^{-1} \ldots$ & \\
\hline 4.1 & 1.1 & 47 & 0.2 & 0.1 & 1.0 & 4.7 & 6.1 & 19.7 & 6.9 & 70.4 & 575 & 50 & 375 \\
\hline
\end{tabular}

$\mathrm{P}=$ Phosphorus; $\mathrm{K}=$ Potassium; $\mathrm{Ca}=$ Calcium; $\mathrm{Mg}=$ Magnesium; $\mathrm{Al}=$ Aluminum; $\mathrm{H}=$ Hydrogen; $\mathrm{CEC}=$ Cation exchange capacity at $\mathrm{pH} 7.0 ; \mathrm{OM}=\mathrm{Organic}$ matter; $\mathrm{V}=\mathrm{Base}$ Saturation; $\mathrm{m}=$ aluminum saturation.
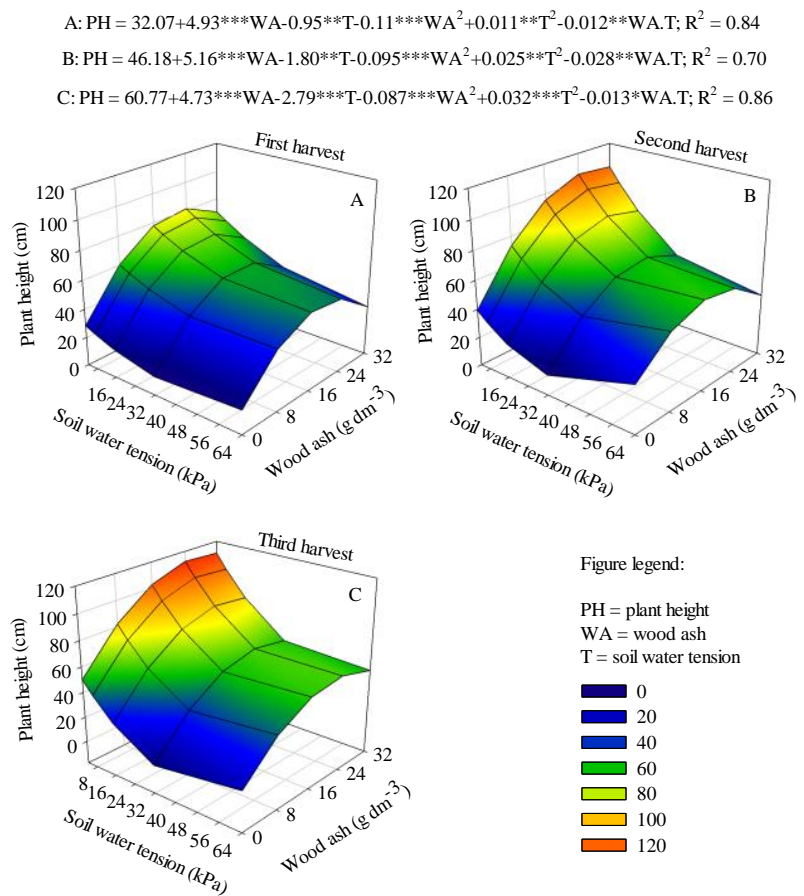

Fig 1. Plant height $(\mathrm{PH})$ of Urochloa brizantha cv. Paiaguás submitted to wood ash (WA) doses $\left(\mathrm{g} \mathrm{dm}^{-3}\right)$ and soil water tensions - $\mathrm{T}$ $(\mathrm{kPa})$ in the first $(\mathrm{A})$, second $(\mathrm{B})$ and third $(\mathrm{C})$ harvest. ${ }^{*},{ }^{* *}$ and ${ }^{* * *}$ significant at 5,1 and $0.1 \%$ of probability. The values in the legend indicate the plants height.

Table 2. Chemical composition of the wood ash used.

\begin{tabular}{|c|c|c|c|c|c|c|c|c|c|c|c|c|c|}
\hline pH & $\mathrm{N}$ & $\mathrm{P}_{2} \mathrm{O}_{5}$ & $\mathrm{~K}_{2} \mathrm{O}$ & $\mathrm{Ca}$ & $\mathrm{Mg}$ & $\mathrm{SO}_{4}$ & $\mathrm{Zn}$ & $\mathrm{Cu}$ & $\mathrm{Fe}$ & $\mathrm{Mn}$ & B & $\mathrm{Si}$ & $\mathrm{Na}$ \\
\hline $\mathrm{CaCl}_{2}$ & & 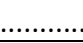 & $\ldots \ldots$ & $\ldots .$. &. $\mathrm{g} \mathrm{kg}^{-}$ & $\ldots \ldots$ & $\ldots \ldots$ & $\ldots \ldots$ & $\ldots \ldots \ldots$ & & & & \\
\hline 10.7 & 3.1 & 9.6 & 34.7 & 33.0 & 21.0 & 2.0 & 0.1 & 0.0 & 10.3 & 0.4 & 0.1 & 274.4 & 0.1 \\
\hline
\end{tabular}

$\mathrm{N}=$ Nitrogen; $\mathrm{P}_{2} \mathrm{O}_{5}=$ Phosphorus in neutral ammonium citrate and water; $\mathrm{K}_{2} \mathrm{O}=$ Potassium; $\mathrm{Ca}=$ Calcium; $\mathrm{Mg}=\mathrm{Magnesium} ; \mathrm{SO}_{4}=\mathrm{Sulfur} ; \mathrm{Zn}=$ Total Zinc; $\mathrm{Cu}=$ Total Copper; $\mathrm{Mn}=$ Total Manganese; $\mathrm{B}=$ Total Boron; $\mathrm{Si}=$ Silicon; $\mathrm{Na}=$ Sodium.
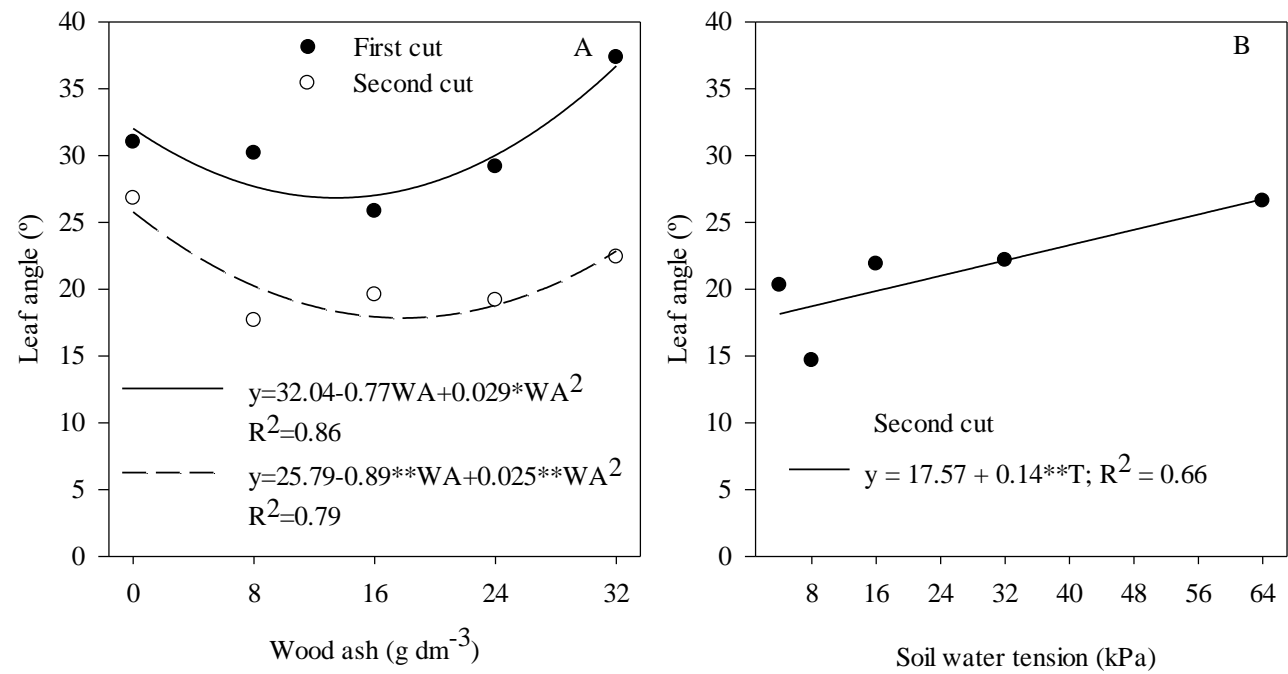

Fig 2. Leaf angle of Urochloa brizantha cv. Paiaguás under wood ash doses $\left(\mathrm{g} \mathrm{dm}^{-3}\right)(\mathrm{A})$ and soil water tension (kPa) (B) at first and second harvests. * and $* *$ significant at 5 and $1 \%$ of probability. 
Table 3. Soil volumetric moisture $\left(\mathrm{cm}^{3} \mathrm{~cm}^{-3}\right)$ corresponding to the water tension ( $\mathrm{kPa}$ ) of the dystrophic Oxisol subjected to doses of wood ash $\left(\mathrm{g} \mathrm{dm}^{-3}\right)$

\begin{tabular}{|c|c|c|c|c|c|}
\hline & Wood a & & & & \\
\hline & 0 & 8 & 16 & 24 & 32 \\
\hline Tensions (kPa) & Soil vol & ture $\left(\mathrm{cm}^{3}\right.$ & & & \\
\hline 4 & 12.835 & 13.662 & 20.036 & 16.338 & 20.356 \\
\hline 8 & 8.498 & 9.822 & 14.505 & 11.545 & 14.778 \\
\hline 16 & 5.626 & 7.062 & 10.506 & 8.158 & 10.728 \\
\hline 32 & 3.725 & 5.077 & 7.603 & 5.765 & 7.789 \\
\hline 64 & 2.466 & 3.650 & 5.504 & 4.073 & 5.654 \\
\hline
\end{tabular}
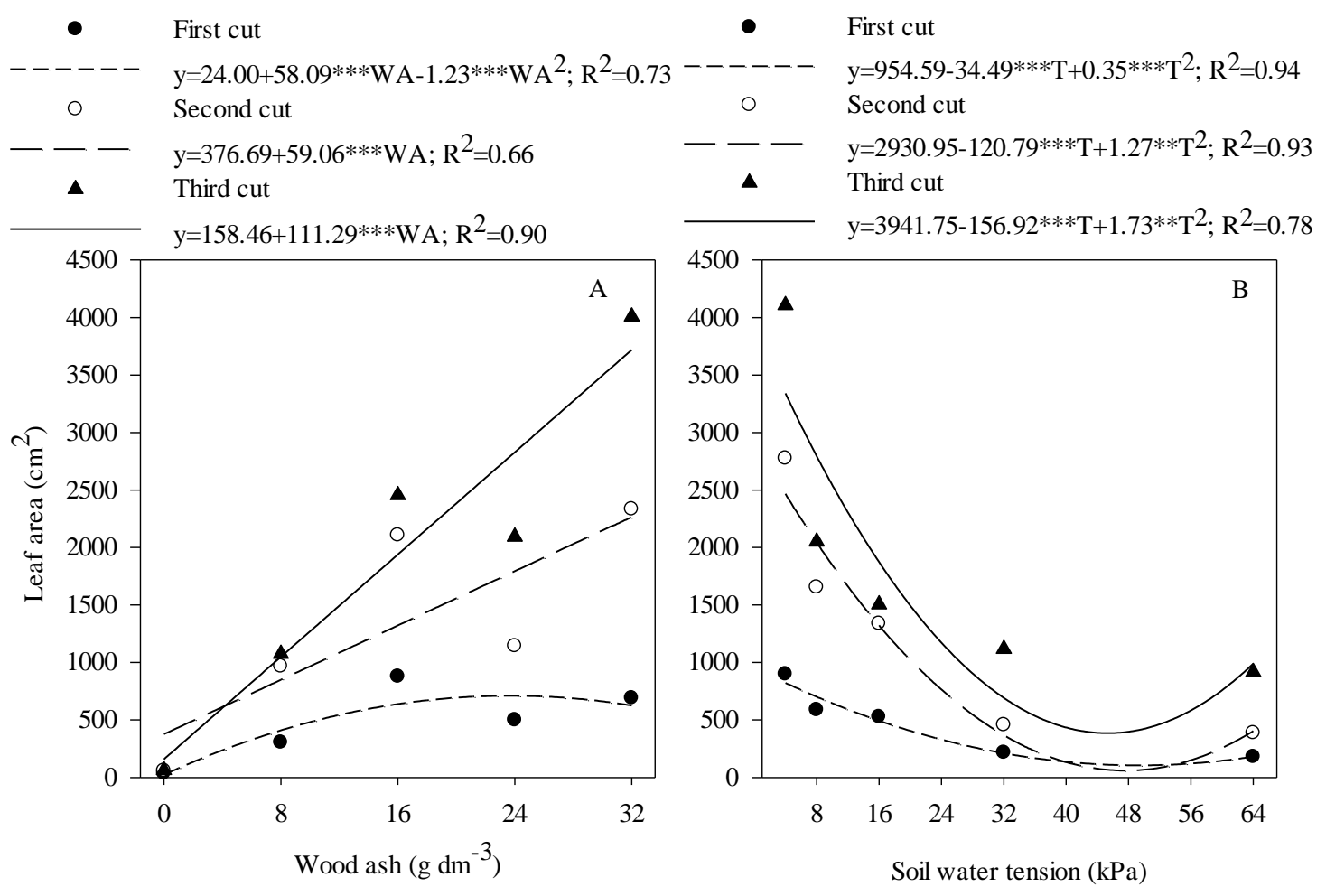

Fig 3. Leaf area of Urochloa brizantha cv. Paiaguás submitted to wood ash doses (A) and soil water tension (B) in the first, second and third harvest. $\mathrm{WA}=$ wood ash. $\mathrm{T}=$ soil water tension. ${ }^{* *}$ and ${ }^{* * *}$ significant at 1 and $0.1 \%$ of probability.
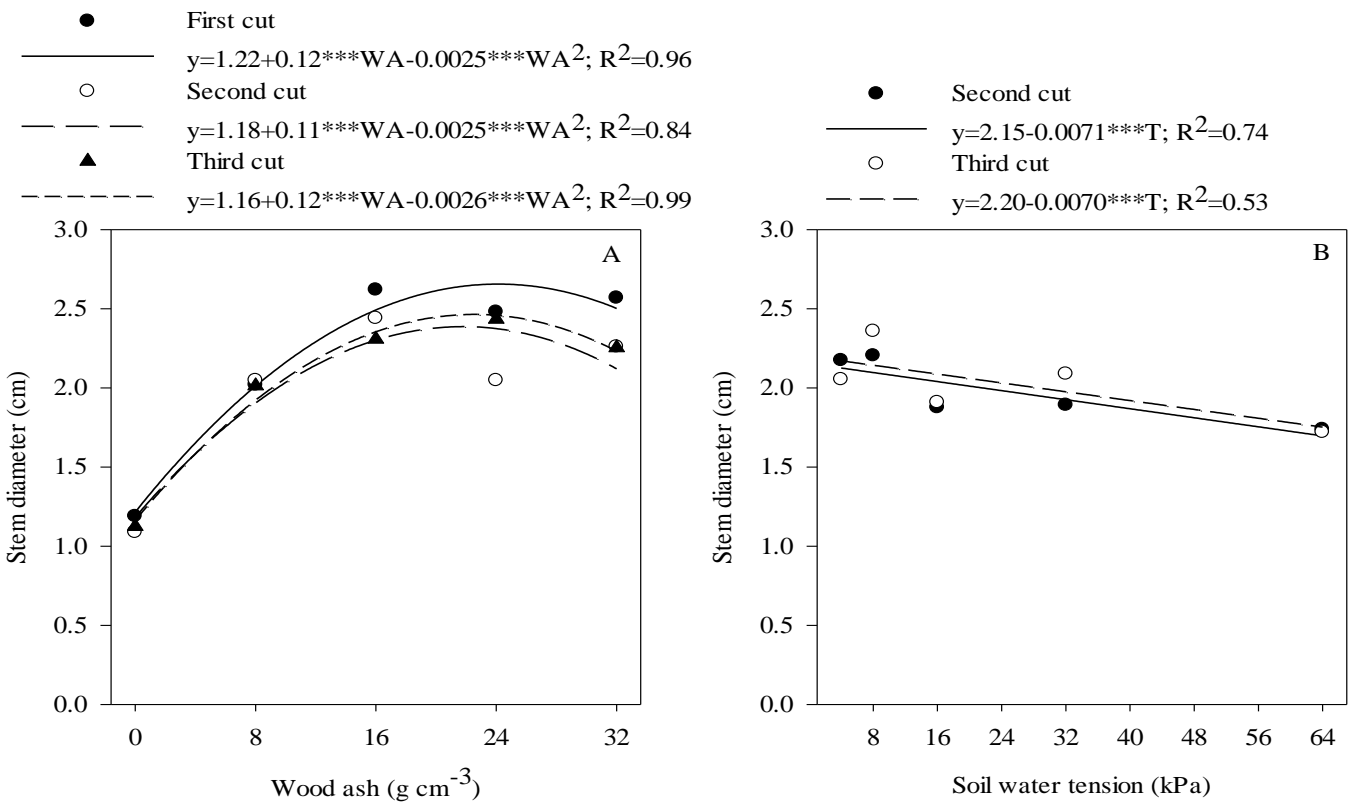

Fig 4. Stem diameter of Urochloa brizantha cv. Paiaguás as a function of wood ash doses (A) and soil water tension (B) in the first, second and third harvests. $* * *$ significant at $0.1 \%$ of probability. 


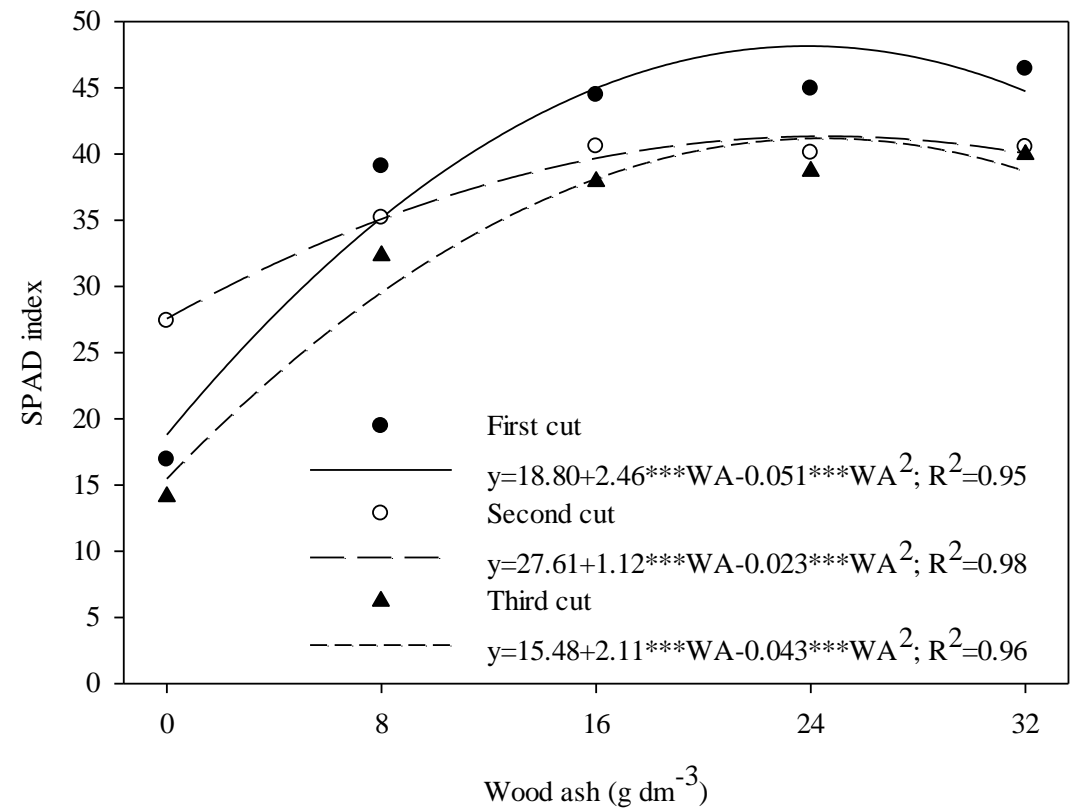

Fig 5. Chlorophyll index (SPAD index) of Urochloa brizantha cv. Paiaguás as a function of wood ash doses in the first, second and third harvests. $* * *$ significant at $0.1 \%$ of probability.

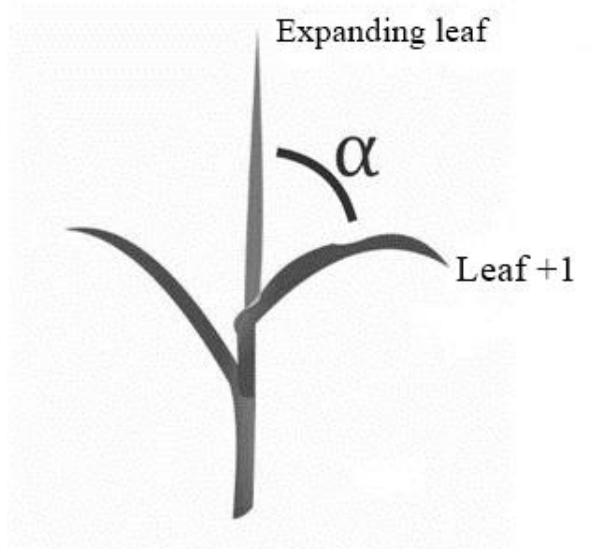

Fig 6. Angle between leaf +1 and the expanding leaf of Urochloa brizantha cv. Paiaguás. Source: The authors.

$48.16,41.35$ and 41.20 , were observed in the $23.87,24.50$ and $24.41 \mathrm{~g} \mathrm{dm}^{-3}$, respectively.

It was observed that wood ash doses of $23.87 ; 24.50$ and $24.41 \mathrm{~g} \mathrm{dm}^{-3}$ provided the highest SPAD readings and provided to the grass $828.29 ; 850.15$ and $847.03 \mathrm{~g} \mathrm{dm}^{-3}$ of potassium $\left(\mathrm{K}_{2} \mathrm{O}\right)$ in the first, second and third harvests, respectively. Thus, it is possible to infer that the contribution of potassium by means of wood ash contributed to the increase of SPAD reading. Potassium is involved in photosynthesis and regulates the opening and closing of stomata. According to Peoples and Koch (1979), the deficiency of this nutrient in the leaf affects the opening of stomata, resulting in a lower assimilation of $\mathrm{CO}_{2}$ in chloroplasts, reducing the photosynthetic rate and increasing respiration and/or transpiration rate.

The wood ash also provided a supply of $501.27 ; 514.50$ and $512.61 \mathrm{~g} \mathrm{dm}^{-3}$ of magnesium in doses that provided the maximum reading points of SPAD in the three harvests. Magnesium is an indispensable enzymatic activator in the photosynthesis, since it occupies central position of chlorophyll molecule (Taiz and Zeiger, 2013). This nutrient corresponds to $2.7 \%$ of chlorophyll molecular mass and represents about $20 \%$ of total leaf magnesium (Mengel and Kirkby, 2001). Thus, the amount of available magnesium can influence the amount of chlorophyll produced.

It is understood that chlorophylls are photosynthetic pigments responsible for the absorption of solar energy and that the main pigments responsible for photosynthesis are chlorophylls (Blackburn, 2007).

The SPAD reading of Paiaguás grass fertilized with wood ash in the three harvests, presented maximum point, greater than 41 units. In general, SPAD reading above 40 generally suggests good nitrogen nutrition while units around 20 to 25 
indicate a clear nitrogen deficiency (Yang et al., 2014a; Yang et al., 2014b).

Considering researches that show significant and positive correlation between the chlorophyll index and the leaf nitrogen concentration (Bullock and Anderson, 1998; Chapman and Barreto, 1997; Malavolta et al., 2004; Yang et al., 2014a), it is possible to manage and obtain instantaneous information, on the grass nutritional status directly in the field, in terms of nitrogen and also to verify the efficiency of fertilization to optimize the management of nitrogen fertilization of pasture.

By means of the present study, it was possible to observe that the application of the wood ash provided a greater retention of water in the soil, because the development of Paiaguás grass began to be reduced in soil water tensions higher than $41.20 \mathrm{kPa}$.. Thus, the results demonstrated the importance of wood ash in the soil to maintain grass in periods of water deficit.

\section{Materials and Methods}

\section{Location and experimental field design}

The experiment was carried out at the Universidade Federal de Mato Grosso, Campus Rondonópolis.

The treatments were arranged in a greenhouse, in randomized complete blocks in a $5 \times 5$ fractional factorial scheme with five replications, corresponding to five doses of wood ash $\left(0,8,16,24\right.$ and $\left.32 \mathrm{~g} \mathrm{dm}^{-3}\right)$ and five soil water tensions $(4 ; 8 ; 16 ; 32 ; 64 \mathrm{kPa})$. The experiment was carried out in a greenhouse in a randomized block design in a $5 \times 5$ fractional factorial scheme. The treatments were composed of five doses of wood ash $\left(0,8,16,24\right.$ and $\left.32 \mathrm{~g} \mathrm{dm}^{-3}\right)$ and five soil water tensions $(4,8,16,32,64 \mathrm{kPa})$, with five replications. The experimental design was based on the modified central compound of Littel and Mott (1975). In this way, 13 combinations of wood ash doses and soil water tensions were studied, respectively: 0-4; 0-16; 0-64; 8-8; 832 ; $16-4 ; 16-16$; $16-64 ; 24-8 ; 24-32 ; 32-4 ; 32-16$; 32-64. The experimental units were composed of pots made of PVC (polyvinyl chloride) pipes $300 \mathrm{~mm}$ high by $200 \mathrm{~mm}$ in diameter, according to Pacheco et al. (2018).

We added $8.7 \mathrm{dm}^{3}$ of a Dystrophic Oxisol to each pot, which was collected from the $0-20 \mathrm{~cm}$ layer in an area under Cerrado vegetation. The soil was sieved in a $4 \mathrm{~mm}$ mesh to fill the pots. Its granulometric composition indicated to be a sandy clay soil (Table 1), according to EMBRAPA (2017).

Wood ash (Table 2) was added to the soil as corrective and fertilizer according to the pre-established doses, remaining for a period of 30 days for the soil correction reaction. The ash was obtained by the combustion of vegetable materials composed of Brachiaria, corn straw, cotton residue, eucalyptus chip, rubber tree and sugarcane bagasse, corresponding to $70 \%$ of biomass, and $30 \%$ of eucalyptus. The combustion temperature of the plant material varied from 200 to $250^{\circ} \mathrm{C}$ and the furnace temperature, from 820 to $850^{\circ} \mathrm{C}$. Wood ash presented a relative neutralizing power (PRNT) equal to $32.66 \%$, neutralization power (PN) of $21.8 \%$, reactivity (RE) of $149.8 \%$ and density of $0.46 \mathrm{~g} \mathrm{~cm}^{-3}$.

After the soil-wood ash incubation period, sowing of $U$. brizantha CV. BRS Paiaguás was carried out, leaving five plants per pot. Nitrogen fertilization (urea) was performed with $200 \mathrm{mg} \mathrm{dm}^{-3}$ (Bonfim-Silva et al., 2015). Nitrogen application occurred via water solution and was split into two applications, with a seven-day interval, beginning five days after emergence of the seedlings to establish the crop. Nitrogen was also applied seven days after each grass harvest, in the maintenance phase.

The management of soil volumetric moisture was performed using the Diviner $2000^{\circ}$ capacitance probe. Soil moisture was related to soil water tension in a pilot experiment with the same soil and the same wood ash doses. In order to increase soil moisture to the established values of each treatment (4, $8,16,32$ and $64 \mathrm{kPa})$, the water was replaced by a semiautomated drip irrigation system (Pacheco et al., 2018) (Table 3). Soil water tensions were applied along with the application of wood ash at the beginning of the incubation period (30 days before sowing).

The volume of water applied to the soil was calculated using the following equation:

$V=\left(\theta_{\text {trat }}-\theta_{\text {actual }}\right) \times 8700$

On what:

$\mathrm{V}=$ volume of water applied $\left(\mathrm{cm}^{3}\right) ; \theta_{\text {trat }}=$ treatment humidity $\left(\mathrm{cm}^{3} \mathrm{~cm}^{-3}\right) ; \theta_{\text {actual }}=$ current soil moisture $\left(\mathrm{cm}^{3} \mathrm{~cm}^{-3}\right)$; $8700=$ volume of soil in the adapted pot $\left(\mathrm{cm}^{3}\right)$.

\section{Description of evaluations}

The response variables were evaluated in the interval of 30 days until completing 90 days after sowing. The height of plants, leaf angle, leaf area, stalk diameter and chlorophyll index (SPAD reading) were evaluated at each grass harvest. The height of plants $(\mathrm{cm})$ corresponded to the measure of the aerial part of the grass, from the surface of the soil to the apex of the leaves of all the plants, by means of a graduated ruler. The leaf angle was measured in degrees (ㅇ) with the aid of a protractor and corresponded to the slope between leaf +1 and leaf expansion (Fig 6), using the average of three values per experimental unit.

The leaf area (in $\mathrm{cm}^{2}$ ) was evaluated by the indirect meter $\mathrm{LI}-$ $3100 \mathrm{C}$ (LI-COR, 1996). The stem diameter $(\mathrm{cm})$ was evaluated at $5 \mathrm{~cm}$ from the soil surface, using a digital caliper from the average of three plants per pot.

The chlorophyll index (SPAD reading) was obtained using the SPAD-502 portable meter (MINOLTA CAMERA CO., 1989). The SPAD readings were performed in five diagnostic leaves of the grass (leaves +1 and +2 ), avoiding the central leaf veins (MONTEIRO, 2010). After readings, an average was obtained for each experimental unit.

\section{Statistical analyses}

Data were submitted to analysis of variance. In case of significant results, a regression analysis was performed. Response variables that presented significance for the interaction between wood ash doses and water availability were analyzed by means of the response surface with PROC RSREG of SAS - Statistical Analysis System (SAS Institute, 2002) software. For the variables that presented isolated effects, the statistical program SISVAR (Ferreira, 2011) was used. All results were considered significant when $p \leq 0.05$.

\section{Conclusion}

The wood ash dose of $20.13 \mathrm{~g} \mathrm{dm}^{-3}$ combined with soil water tension of $47.29 \mathrm{kPa}$ provided higher plant height. Wood ash 
incorporated into the soil provided greater leaf area development, stem diameter and chlorophyll index of Paiaguás grass and lower leaf angles of plants. High soil water tensions reduced the development of forage grass.

\section{References}

Bezerra MDL, Bonfim-Silva EM, Silva TJA (2014) Wood ash effect on the productive characteristics of Marandu grass in Cerrado soils. Afr J Agric Res. 9:2339-2344

Blackburn, GA (2007) Hyperspectral remote sensing of plant pigments. J Exp Bot. 58:855-867.

Bonfim-Silva EM, Nunes JAS, Silva TJA, Pacheco AB (2016) Initial growth of millet under bulk density levels in oxisol of the Cerrado. Int J Curr Res. 8:34793-34798.

Bonfim-Silva EM, Santos CC, Silva TJA (2015) Wood ash fertilization on structural characteristics and chlorophyll index of tropical forage grasses. Am J Plant Sc. 6:13411348.

Bullock DG, Anderson DS (1998) Evaluation of the Minolta SPAD-502 chlorophyll meter for nitrogen management in corn. J Plant Nutr. 21:741-755.

Chapman SC, Barreto HJ (1997) Using a chlorophyll meter to estimate specifc leaf nitrogen of tropical maize during vegetative growth. Agro J Abs. 89:557-562.

Chaugool J, Kondo M, Kasuga S, Naito H, Goto M, Ehara H (2013) Nutritional evaluation and in vitro ruminal fermentation of Sorghum cultivars. J Food Agric Env. 11:345-351

Chen W, Jensen PE, Ottosen LM, Kirkelund GM (2015) Electrodialytic remediation of fly ash from co-combustion of wood and straw. Electro Acta. 181:208-216.

Costa JAA, Queiroz HP (2017) Régua de manejo de pastagens. ed rev. Com Téc 125 EMBRAPA, Campo Grande $7 p$.

Dabrowski P, Pawluśkiewicz B, Kalaji HM, Baczewska AH (2013) The effect of light availability on leaf area index, biomass production and plant species composition of park grasslands in Warsaw. Plant Soil Env. 59:543-548.

Drewry DT, Kumar P, Long SP (2014) Simultaneous improvement in productivity, water use, and albedo through crop structural modification. Glob Change Bio. 20:1955-1967.

EMBRAPA - Empresa Brasileira de Pesquisa Agropecuária Centro Nacional de Pesquisa de Solos (2017) Manual de métodos de análises de solo. 3rd edn. Embrapa, Brasília 573p.

Euclides VPB, Montagner DB, Barbosa RA, Valle CB, Nantes NN (2016) Animal performance and sward characteristics of two cultivars of Brachiaria brizantha (BRS Paiaguás and BRS Piatã). Rev Bras Zoot. 45:85-92.

Ferreira DF (2011) Sisvar: a computer statistical analysis system. Ciênc Agrotec. 35:1039-1042.

Fonseca L, Carvalho PCF, Mezzalira JC, Bremm C, Galli JR, Gregorini P (2013) Effect of sward surface height and level of herbage depletion on bite features of cattle grazing Sorghum bicolor swards. J Anim Sci. 91:4357-4365.

Holder CD (2012) The relationship between leaf hydrophobicity, water droplet retention, and leaf angle of common species in a semi-arid region of the western United States. Agric Forest Met. 152:11-16.
Kebrom TH, Mullet JE (2015) Photosynthetic leaf area modulates tiller bud outgrowth in sorghum. Plant Cell Env. 38:1471-1478.

Koch K, Bohn HF, Barthlott W (2009) Hierarchically sculptured plant surfaces and superhydrophobicity. Langmuir. 25:14116-14120.

Koetz M, Bär CSLL, Pacheco AB, Castro WJR, Crisostomo WL, Silva EMB (2017) Produção e eficiência no uso da água do capim paiaguás sob tensões de água no solo. Rev Bras Agric Irrig. 11:1223-1232.

LI-COR (1996) LI-3100 area meter instruction manual. Lincoln. 34p.

Littell RC, Mott GO (1975) Computer assisted design and analysis of response surface experiments in agronomy. Soil Crop Soc Florida Proc. 34:94-97.

Mahajan S, Tuteja N (2005) Cold, salinity and drought stresses: an overview. Arch Biochem Biophysics. 444:139158.

Malavolta E, Nogueira NGL, Heinrichs R, Higashi EN, Rodriguez V, Guerra E, Oliveira SC, Cabral CP (2004) Evaluation of nutritional status of the cotton plant with respect to nitrogen. Commun Soil Sci Plant Analysis. 35:1007-1019.

Malmgren A, Riley G (2012) Biomass power generation. Ref Mod Earth Sys Env Sci. 5:27-53.

McMahon C, Kronauer RE (1976) Tree structures: deducing the principle of mechanical design. J Theor Bio. 59:443466.

MENGEL K, KIRKBY EA (2001) Principles of Plant Nutrition. 5th edn. Kluwer Academic Publishers 849p.

MINOLTA CAMERA CO (1989) Manual for chlorophyll meter SPAD-502. Osaka: Minolta Radiometric Instruments Divisions 22p.

Monteiro FA (2010) Pastagens. In: Prochnow LI, Casarin V, Stipp SR (ed). Boas práticas para uso eficiente de fertilizantes. IPNI, Piracicaba c6:231-285.

Niklas KJ (1994) Plant allometry: the scaling of form and process. University of Chicago Press, Chicago.

Pacheco AB, Silva TJA, Bonfm-Silva EM, Castro HAW, Koetz $M$ (2018) Yield and water use of cherry tomato under water availability and potassium doses. Rev Bras Eng Agríc Amb. 22:326-331.

Peoples TR, Koch DW (1979) Role of potassium in carbon dioxide assimilation in Medicago sativa L. Plant Phys. 63:878-881.

Pezzopane CG, Santos PM, Cruz PG, Altoé J, Ribeiro FA, Valle CB (2015) Estresse por deficiência hídrica em genótipos de Brachiaria brizantha. Ciênc Rural. 45:871-876.

Ring E, Jacobson S, Nohrstedt HÖ (2006) Soil-solution chemistry in a coniferous stand after adding wood ash and nitrogen. Canad J Forest Res. 36:153-163.

Rodrigues LF, Santos AC, Silveira Júnior O, Santos JGD (2017) Productivity of Urochloa brizantha 'Marandu' influenced by strategic rest periods and nitrogen levels. Semina: Ciênc Agr. 38:3203-3214.

Saarsalmi A, Smolander A, Kukkola M, Moilanen M, Saramäki $J$ (2012) 30-year effects of wood ash and nitrogen fertilization on soil chemical properties, soil microbial processes and stand growth in a scots pine stand. Forest Ecol Manag. 278:63-70. 
Santos CC, Bonfim-Silva EM, Silva TJA (2014) Tropical grass fertilized with wood ash in Cerrado oxisol: concentrations of calcium, magnesium and sulphur. Afr J Agric Res. 9:1495-1501.

Santos MER, Simplício MG, Silva GP, Oliveira HA, Costa LKP, Sousa DOC (2017) Reduction of sward height in the fall and winter as a strategy to improve the structure of marandu palisadegrass (Urochloa brizantha syn Brachiaria brizantha cv Marandu) Trop Grass - Forr Trop. 5:143-152.

Santos PM, Cruz PG, Araújo LC, Pezzopane JRM, Valle CB, Pezzopane CG (2013) Response mechanisms of Brachiaria brizantha cultivars to water deficit stress. Rev Bras Zootec. 42:767-773.

SAS INSTITUTE (2002) SAS: user's guide. 9 ed. SAS Institute, Carry, NC.

Song QF, Zhang GL, Zhu XG (2013) Optimal crop canopy architecture to maximise canopy photosynthetic $\mathrm{CO}_{2}$ uptake under elevated $\mathrm{CO}_{2}$ : a theoretical study using a mechanistic model of canopy photosynthesis. Funct Plant Bio. 40:109-124.

Souza GM, Ballester VR, Cruz CHB, Chum H, Dale B, Dale VH, Fernandes ECM, Foust $T$, Karp A, Lynd L, Maciel Filho R, Milanez A, Nigro F, Osseweijer P, Verdade LM, Victoria RL, Wielen LV (2017) The role of bioenergy in a climatechanging world. Env Develop. 23:57-64.

Symanowicz B, Becher M, Jaremko D, Skwarek K (2018) Possibilities for the use of wood ashes in agriculture. J Ecol Eng. 19:191-196.
Taiz L, Zeiger E (2013) Plant physiology, 5th edn. Sinauer Associates, Sunderland.

Truong SK, McCormick RF, Rooney WL, Mullet JE (2015) Harnessing genetic variation in leaf angle to increase productivity of sorghum bicolor. Genetics. 201:1229-1238.

Valle $C B$, Euclides VPB, Montagner DB, Valério JR, Fernandes CD, Macedo MCM, Verzignassi JR, Machado LAZ (2013) BRS Paiaguás: a new Brachiaria (Urochloa) cultivar for tropical pastures in Brazil. Trop Grass - Forr Trop. 1:121122

Vassilev SV, Baxter D, Andersen LK, Vassileva CG (2013) An overview of the composition and application of biomass ash Part 1 Phase-mineral and chemical composition and classification. Fuel. 105:40-76.

Van Zanten M, Pons TL, Janssen JAM, Voesenek LACJ, Peeters AJM (2010) On the relevance and control of leaf angle. Cri Rev Plant Sci. 29:300-316

Watson DJ (1952) The physiological basis of variation in yield. Adv Agr. 4:101-145.

Yang H, LI J, Yang J, Wang H, Zou J, He J (2014b) Effects of nitrogen application rate and leaf age on the distribution pattern of leaf SPAD readings in the rice canopy. Plos One. 9:e88421.

Yang H, Yang J, Lv Y, He J (2014a) SPAD Values and nitrogen nutrition index for the evaluation of rice nitrogen status. Plant Prod Sci. 17:81-92. 